\title{
FENO ŞI ATOPIA ÎN ASTMUL BRONŞIC LA COPII
}

\author{
Cristiana Stănciulescu', Mirela Chiru' ${ }^{1,2}$, Alina Oprea1, Daniela Păcurar1, ${ }^{1,2}$ \\ Carmen Zăpucioiu, ${ }^{1,2}$, Elena Petrişor ${ }^{1}$, Dumitru Orăşeanu ${ }^{1,2}$ \\ ${ }^{1}$ Spitalul Clinic de Urgență pentru Copii ,, Grigore Alexandrescu“, Bucureşti \\ ${ }^{2}$ Universitatea de Medicină şi Farmacie ,, Carol Davila“, Bucureşti
}

\section{REZUMAT}

Obiective. Stabilirea relației între valoarea concentrației oxidului nitric expirat (FENO) şi atopia în astmul bronşic la copii.

Metode. Au fost examinați 92 de pacienți cu diagnosticul de astm bronşic stabilit, cu vârste cuprinse între 5 şi 18 ani, care s-au prezentat în Clinica de Pediatrie a Spitalului Clinic de Urgențe pentru Copii „Grigore Alexandrescu“. Terenul atopic a fost evaluat prin date anamnestice, clinice şi investigații de laborator (eozinofile serice şi IgE totale). Tuturor pacienților li s-a determinat concentrația oxidului nitric expirat.

Rezultate. S-au obținut valori crescute ale FENO la copiii cu astm bronşic alergic față de cei cu astm bronşic nonalergic, valori care se corelează cu eozinofilia şi creşterea imunoglobulinelor $E$ totale.

Concluzii. Măsurarea FENO este utilă pentru evaluarea inflamației mucoasei bronşice la copiii cu astm bronşic atopic.

\section{INTRODUCERE}

Astmul bronşic (AB) este o boală cronică, heterogenă, a cărei patogenie este parțial cunoscută. Oxidul nitric, marker al inflamației căilor aeriene (1), este tot mai mult utilizat pentru stabilirea corelației cu diferitele fenotipuri de AB. Creşterea oxidului nitric este considerată patognomonică în inflamaţia eozinofilică. (2); s-au dovedit valori crescute ale FENO la pacienții cu astm bronşic atopic. (3)

\section{SCOPURI ŞI OBIECTIVE}

Măsurarea fracției oxidului nitric în aerul expirat este o metodă simplă, neinvazivă, uşor de efectuat, bine tolerată, care nu implică niciun risc. Creşterea valorilor oxidului nitric se corelează cu creşterea citokinelor serice inflamatorii (4).

Prin studiul realizat în clinica noastră ne-am propus stabilirea corelaţiei între FENO şi datele anamnestico-clinice şi paraclinice care atestă terenul atopic, contribuția FENO la definirea fenotipului alergic al AB la copil.

\section{MATERIAL ŞI METODĂ}

Studiul realizat în clinica noastră a inclus 92 pacienți cu diagnosticul de AB stabilit (cod ICD 10 din 2014-J 45), cu vârsta cuprinsă între 5-18 ani. Au fost excluşi din studiu pacienții care nu au reuşit efectuarea corectă a manevrei de măsurare a oxidului nitric (FENO) şi cei care prezentau la momentul evaluării infecții acute de căi respiratorii. $\mathrm{Au}$ fost notate datele anamnestice care relatează prezența atopiei la rudele de gradul I(AHC) şi antecedentele personale patologice (APP) atopice.

Studiul s-a desfãşurat în perioada ianuarie 2013 - ianuarie 2014, cu aprobarea Comisiei de Etică Medicală a S.C.U.C. „Grigore Alexandrescu“.

Pacienții din studiu au fost împărțiți în două subgrupe folosind ca parametru vârsta - copii cu vârsta 5-12 ani, respectiv 13-18 ani. Cele două subgrupe au fost analizate în funcție de antecedentele atopice, eozinofilele serice, imunoglobulinele $\mathrm{E}$ totale şi FENO.

Examenul ORL a evidențiat prezența rinitei alergice la unii pacienți. 


\section{Analiza statistică}

Analiza statistică a fost realizată folosind programul de statistică SPSS pentru Windows 21.0 (IBM SPSS, IBM Ireland, Dublin, Ireland). Variabilele cantitative normal distribuite (funcționale, biochimice şi imunologice) au fost exprimate ca medii \pm eroarea standard a mediei (SEM) şi analizate cu testul Student T-test sau analiza Oneway Anova cu testul LSD Post-hoc. A fost calculată distribuția crosstabs cu analiza chi-squared $\left(\chi^{2}\right)$ pentru a evalua diferențele între datele logistice (sexul, grupa de vârstă, diagnosticul). A fost realizată analiza de corelație parametrică bivariată a FENO cu eozinofilele serice şi IgE totale, folosind funcția Pearson şi valoarea $\mathrm{p}$ asociată. Au fost estimate modele de regresie liniară multiplă ale nivelurilor FENO (ca variabilă dependentă) cu IgE şi eozinofilele (ca variabile independente-predictori), iar valorile $\mathrm{R}^{2}$ corectate au fost folosite ca scor de predicție pentru variația FENO (cu verificarea pentru corecția modelului cu scorul funcției $\mathrm{F}$ şi analiza Durbin-Watson). A fost făcută analiza de regresie logistică binară (LR) cu metoda de iterație enter pentru discriminarea între grupele $\mathrm{cu} A \mathrm{~B}$ (binare), considerând grupul $\mathrm{cu} \mathrm{AB}$ non-alergic categorie de referință (0), iar grupul cu $\mathrm{AB}$ alergiccategorie de risc (1), în timp ce FENO (ppb), eozinofilele (\% num), IgE (IU/ml), grupa de vârstă, sexul, atopia, rinita, AHC de atopie au fost introduse în modelul LR ca şi covariate (parametrii independenți). Pragul pentru semnificație statistică a fost setat la $5 \%$ (valori $\mathrm{p}<0,05)$.

\section{REZULTATE}

Distribuția AB alergic pe subgrupe la cei 92 de copii studiați nu diferă semnificativ în funcție de grupa de vârstă, prezența atopiei, rinitei sau AHC de atopie $(p>0,05)$. Totuşi, o contribuție importantă o are diagnosticul de rinită (OR 3.261), 28,1\% fiind cu AB alergic, comparativ cu 10,7\% AB nonalergic, însă aceasta distribuție nu este semnificativă statistic, probabil şi datorită numărului de cazuri.

Valorile medii ale parametrilor măsurați FENO, eozinofile si IgE diferă în funcție de diagnosticul de $\mathrm{AB}$ alergic, fiind statistic semnificativ crescut în aceasta grupă comparativ cu $\mathrm{AB}$ non-alergic $(\mathrm{p}<0,05$, Tabelul 1).

Valorile FENO la subiecții studiați se corelează statistic semnificativ cu nivelurile eozinofilelor şi $\operatorname{IgE}(p<0,05$, Tabelul 2). La analiza corelațiilor observate pe subgrupe, se observă ca FENO se corelează statistic semnificativ cu eozinofilele, dar
TABELUL 1. Valori medii ale parametrilor măsurați la subgrupele de subiecți studiați

\begin{tabular}{|c|c|c|c|}
\hline Parametru & Subgrupa & Medie \pm SEM & p-value \\
\hline FENO (ppb) & $\begin{array}{l}\text { AB } \\
\text { Non-alergic } \\
\text { Alergic } \\
\text { Vârsta } \\
\text { 5-12 ani } \\
\text { 13-18 ani } \\
\text { Atopie } \\
\text { Nu } \\
\text { Da } \\
\text { Rinita } \\
\text { Nu } \\
\text { Da } \\
\text { Total }(n=92)\end{array}$ & $\begin{array}{c}11,67 \pm 2,47 \\
26,26 \pm 4,76 \\
18,62 \pm 3,02 \\
35,12 \pm 11,59 \\
19,39 \pm 2,96 \\
29,24 \pm 10,48 \\
22,81 \pm 4,12 \\
17,52 \pm 3,64 \\
21,54 \pm 3,25\end{array}$ & 0,340 \\
\hline $\begin{array}{l}\text { Eozinofile } \\
\text { (\% num) }\end{array}$ & $\begin{array}{l}\text { AB } \\
\text { Non-alergic } \\
\text { Alergic } \\
\text { Vârsta } \\
\text { 5-12 ani } \\
\text { 13-18 ani } \\
\text { Atopie } \\
\mathrm{Nu} \\
\text { Da } \\
\text { Rinita } \\
\text { Nu } \\
\text { Da } \\
\text { Total }(n=92) \\
\end{array}$ & $\begin{array}{l}0,0423 \pm 0,00711 \\
0,0640 \pm 0,00689 \\
0,0551 \pm 0,00585 \\
0,0625 \pm 0,01247 \\
0,0539 \pm 0,00608 \\
0,0641 \pm 0,01066 \\
0,0586 \pm 0,00637 \\
0,0500 \pm 0.00918 \\
0,0564 \pm 0,00527\end{array}$ & $\begin{array}{l}0,591 \\
0,411 \\
0,443\end{array}$ \\
\hline IgE (IU/ml) & $\begin{array}{l}\text { AB } \\
\text { Non-alergic } \\
\text { Alergic } \\
\text { Vârsta } \\
\text { 5-12 ani } \\
\text { 13-18 ani } \\
\text { Atopie } \\
\text { Nu } \\
\text { Da } \\
\text { Rinita } \\
\text { Nu } \\
\text { Da } \\
\text { Total }(n=92)\end{array}$ & $\begin{array}{c}74,31 \pm 13,32 \\
490,45 \pm 60,23 \\
354,43 \pm 54,71 \\
496,40 \pm 95,20 \\
398,08 \pm 61,23 \\
322,81 \pm 57,75 \\
430,47 \pm 62,61 \\
242,03 \pm 48,40 \\
379,49 \pm 48,23\end{array}$ & 0,374 \\
\hline
\end{tabular}

Valori medii şi eroarea standard medie (SEM) ale parametrilor analizați, cu evaluarea diferenței statistice cu funcția Student T-test (prag $\mathrm{p}<0,05)$, după analiza egalității variațiilor (testul Levene). $* p<0,05, * * p<0,01, * * * p<0,001$.

nu cu IgE la subiecții cu AB alergic. De asemenea, FENO se corelează foarte bine cu eozinofilele şi IgE la grupa de vârstă 13-18 ani, probabil datorită unei aprecieri mult mai exacte a acestui parametru la adolescenți, comparativ cu copiii de 5-12 ani.

Gradul de independență al FENO în utilizarea sa ca biomarker în $\mathrm{AB}$ alergic poate fi estimat pe baza variației altor parametri asociați sau utilizați în diagnostic. Analiza de regresie liniară multiplă (multi-parametrică) estimează pe baza variabilei R-squared că o variație cu $10,3 \%$ a FENO este prezisă semnificativ de o variație corespunzătoare a 
eozinofilelor şi $\operatorname{IgE}(\mathrm{p}=0,031$, Tabelul 3). Dacă se ia în calcul şi vârsta subiecților (model 2 în Tabelul 3 ), este estimată o predicție statistic semnificativă a variației FENO cu $16,5 \%(p=0,010)$. Ultimul model care include ca predictori şi o serie de parametri secundari (model 3 în Tabelul 4) creşte gradul de predicție la $30,4 \%(p=0,009)$.

TABELUL 3. Regresia liniară multiplă pentru FENO pe baza variației parametrilor măsurați la subgrupele de subiecți studiați

\begin{tabular}{|l|c|c|c|}
\hline $\begin{array}{l}\text { Regresie liniară } \\
\text { multiplă }\end{array}$ & F score & $\begin{array}{c}\text { Adjusted R } \\
\text { squared }\end{array}$ & p-value \\
\hline Model 1 $^{\text {a }}$ & 3.673 & 0.103 & $0.031^{*}$ \\
\hline Model 2 $^{\text {b }}$ & 4.135 & 0.165 & $0.010^{*}$ \\
\hline Model 3 $^{\text {c }}$ & 2.768 & 0.304 & $0.009^{*}$ \\
\hline
\end{tabular}

${ }^{1}$ Variabilă dependentă: FENO (ppb) $(\mathrm{n}=92)$.

${ }^{*} p<0,05,{ }^{*} p<0,01$ a ariabile independente (predictori): eozinofile

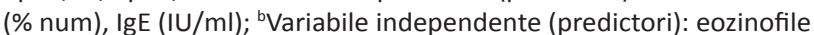

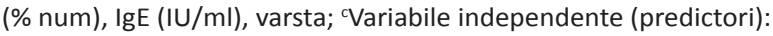
eozinofile (\% num), IgE (IU/ml), varsta.

Riscul de $\mathrm{AB}$ alergic poate fi estimat statistic prin analiza de regresie logistică binară, care ia în calcul atât parametrii continuu distribuiți (Gaussian), dar şi variabile binare (discrete, cum ar fi sexul, grupa de vârstă sau alte diagnostice secundare). Rezultatul acestei analize arată că FENO nu este un biomarker cu semnificație statistică $(p=0,100$, NS) pentru riscul de $\mathrm{AB}$ alergic, deşi variația lui poate prezice corect aproape $76 \%$ dintre cazuri, un scor destul de bun, dar nu puternic (Tabelul 4). Însă FENO poate fi folosit cu succes din punct de vedere al predicției statistice a riscului de $\mathrm{AB}$ alergic doar împreună cu eozinofilele şi IgE în aproape $85 \%$ dintre cazuri ( $\mathrm{p}<0,001$, model 2 în Tabelul 4). Considerarea altor parametri cum sunt grupa vârstă, sex, atopie, rinită, AHC atopie în acest model de regresie logistică binară îmbunătățeşte predicția riscului de $\mathrm{AB}$ alergic până la peste $92 \%$. Dintre aceste covariate, doar rinita este un predictor semnificativ independent $(\mathrm{p}=0,001)$, ceilalți parametri nu au o contribuție semnificativă la estimarea riscului de $\mathrm{AB}$ alergic (Tabelul 4).

\section{DISCUȚII}

Relevanța cercetării noastre este susţinută de numărul redus al studiilor similare efectuate până în prezent pe populația pediatrică (6-13).

În studiul nostru, copiii cu astm alergic au avut niveluri semnificativ crescute ale FENO, eozinofilelor şi imunoglobulinelor E. FENO s-a corelat semnificativ statistic cu nivelurile sanguine ale eozinofilelor şi imunoglobulinelor $\mathrm{E}$, evidențiind corelația existentă între FENO şi fenotipul alergic. Yao şi alții (13) au raportat utilizarea FENO pentru identificarea sensibilizării alergice pe un lot de copii care făceau parte din aceeaşi grupă de vârstă ca şi lotul nostru (5-18 ani). Jackson şi alții (9) au demonstrat că FENO este asociat semnificativ statistic cu astmul şi dermatita atopică. Corelaţia dintre FENO şi statusul atopic a fost, de asemenea, raportată de către Banovcin şi alții (14) care au raportat niveluri mai ridicate ale FENO, IgE totale şi eozinofilelor serice în rândul copiilor astmatici atopici comparativ cu cei non-atopici şi cu cei din lotul de control. Welsh şi colab. (15) au efectuat o analiză multivariată care a relevat faptul că astmul împreună cu febra fânului şi dermatita atopică influențează nivelurile FENO la pacienții pediatrici. Prin urmare, astmul atopic este asociat cu un nivel ridicat al FENO comparativ cu copiii diagnosticați cu astmul non-alergic (14).

Rezultatele noastre corespund cu cele publicate de către Romero şi alții (10) care au concluzionat că FENO nu poate identifica singur cu acuratețe atopia sau astmul. Am identificat faptul că FENO

TABELUL 4. Regresia logistică binară pentru diagnosticul de AB alergic pe baza variației parametrilor măsurați la subgrupele de subiecți studiați

\begin{tabular}{|c|c|c|c|c|c|}
\hline $\begin{array}{l}\text { Regresie } \\
\text { logistică binară }{ }^{1}\end{array}$ & $\begin{array}{c}\text { Predicție AB alergic } \\
\text { (\%) }\end{array}$ & $\begin{array}{l}\text { Chi-square } \\
\text { step }\end{array}$ & $\begin{array}{l}\text { p-value } \\
\text { step }\end{array}$ & $\begin{array}{c}\text { Chi-square } \\
\text { model }\end{array}$ & $\begin{array}{c}\text { p-value } \\
\text { model }\end{array}$ \\
\hline Model $1^{\mathrm{a}}$ & 75,9 & - & - & 2,712 & 0,100 \\
\hline Model $2^{b}$ & 84,8 & 36,398 & $<0,001 * * *$ & 39,111 & $<0,001 * * *$ \\
\hline Model $3^{c}$ & 86,1 & 1,834 & 0,400 & 40,945 & $<0,001^{* * *}$ \\
\hline Model $4^{d}$ & 87,3 & 0,281 & 0,596 & 41,226 & $<0,001 * * *$ \\
\hline Model $5^{e}$ & 92,4 & 11,268 & $0,001 * * *$ & 52,494 & $<0,001^{* * *}$ \\
\hline Model $6^{f}$ & 91,1 & 1,872 & 0,171 & 54,366 & $<0,001 * * *$ \\
\hline
\end{tabular}

${ }^{1}$ Variabilă dependentă: $A B$ alergic. Testul Chi-square pentru coeficieții parametrilor (covariate) în model (B). ${ }^{*} p<0,05,{ }^{* *} p<0,01,{ }^{* * *} p<0,001$. ${ }^{a}$ Covariate (predictori): FENO (ppb); ${ }^{\text {b} C o v a r i a t e ~}$ (predictori): FENO (ppb), eozinofile (\% num), IgE (IU/ml); ${ }^{c}$ Covariate (predictori): FENO (ppb), eozinofile (\% num), IgE (IU/ml), grupa vârstă, sex; ${ }^{d}$ Covariate (predictori): FENO (ppb), eozinofile

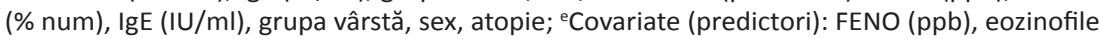
(\% num), IgE (IU/ml), grupa vârstă, sex, atopie, rinită; ${ }^{f}$ Covariate (predictori): FENO (ppb), eozinofile (\% num), IgE (IU/ml), grupa vârstă, sex, atopie, rinită, AHC atopie. 
devine un predictor cu semnificație statistică doar atunci cand alți parametri precum eozinofilele, IgE, vârsta, sexul, atopia, rinita, istoricul familial pozitiv pentru atopie sunt luați în considerare. Astfel, FENO poate fi privit ca un contributor de încredere la definirea fenotipului alergic.

\section{CONCLUZII}

1. FENO este o investigaţie simplă, uşor de efectuat, dar care necesită o bună colaborare din partea pacienților pentru validitatea rezultatelor.
2. Interpretarea valorilor FENO nu se corelează cu vârsta, antecedentele atopice.

3. În astmul bronşic alergic creşte valoarea FENO atunci când se corelează cu eozinofilele serice şi imunoglobulinele $\mathrm{E}$ totale.

4. FENO poate contribui la stabilirea diagnosticului de astm bronşic, alături de probele funcționale respiratorii, şi la definirea fenotipului alergic împreună cu eozinofilele serice şi Ig E totale, semnificativ statistic $(\mathrm{p}<0,001)$. 